Chirurgia (2017) 112: 619-623

No. 5, September - October

Copyright $\odot$ Celsius

http://dx.doi.org/10.21614/chirurgia.112.5.619

\title{
"Mending A Broken Heart!" (a few technical tips on repairing penetrating trauma to the heart)
}

\author{
Myint Tun', John Massalis ${ }^{2}$, Bogdan Diaconescu ${ }^{3}$, Elias Degiannis ${ }^{4}$ \\ 'Department of Surgery, University of the Witwatersrand, Leratong Hospital, Johannesburg, South Africa \\ 2Department of Surgery, Nafplion Hospital, Nafplion, Greece \\ ${ }^{3}$ Carol Davila University of Medicine and Pharmacy \& Surgery Department, Emergency Clinical Hospital Bucharest, Romania \\ ${ }^{4}$ Department of Surgery, University of the Witwatersrand, Milpark Hospital Academic Trauma Centre, Leratong Hospital, \\ Johannesburg, South Africa
}

Corresponding author:

Elias Degiannis, MD

Department of Surgery

University of the Witwatersrand

Milpark Hospital Academic Trauma

Centre, Leratong Hospital,

Johannesburg, South Africa

E-mail: degiannis@yebo.co.za

\section{Rezumat}

"Repararea unei inimi zdrobite!" (câteva sfaturi tehnice privind tratararea leziunilor cardiace penetrante)

Pe parcursul istoriei, sutura leziunilor cardiace a fost considerată a fi imposibil, iar prima cardiorafie a fost efectuată cu succes în urmă cu aproximativ un secol. Tamponada, mai frecvent decât exsanguinarea, este cauza morți în trauma cardiacă penetrantă. Aceasta este o leziune de obicei letală, iar cei care au supraviețit până la spital au o mortalitate generală de aproximativ $80 \%$. Trauma penetrantă necesită nişte paşi de bază, nu o dexteritate operatorie specială. Prezentăm managementul tehnic al acestei leziuni, anumite pericole şi capcane. Opțiunile pentru expunerea chirurgicală, detaliile tehnice ale suturilor leziunilor cardiace şi condițiile excepționale, cum ar fi leziunile vecine arterei coronare, sunt discutate în detaliu. Sunt examinate, de asemenea, datele obținute şi direcțiile viitoare în gestionarea acestei leziuni

Cuvinte cheie: leziune cardiacă penetrantă, sângerare, tamponadă cardiacă, tehnici

\section{Abstract}

During the history operative repair of cardiac injuries was considered to be unmanageable and the first successful cardiomiorraphy was performed just around a century ago. 
Tamponade, more frequently than exsanguination are cause of death in penetrating cardiac trauma. This is a usualy lethal injury and those surviving to hospital have an overall mortality approaching $80 \%$. The penetrating injury require some basic steps, not special operative dexterity. We present the technical management of this injury, certain danger points and pitfalls. Options for surgical exposure, technical details of suturing cardiac injuries, and exceptional conditions such as injury near the coronary artery are discussed in detail. Outcome data and future directions in managing this injury are also examined.

Key words: penetrating cardiac injury, bleeding, cardiac tamponade, techniques

\section{Introduction}

The heart penetrating injury, an uncommon injury in Europe, is an injury that does not require operative dexterity and can have good outcomes if the attending surgeon follows some basic steps. The purpose of this paper is to simplify the technical management of this injury by highlighting certain operative heuristic pearls, danger points and pitfalls, that the authors have come to over the years.

\section{The Incision: Left Anterolateral or Median Sternotomy}

\section{Emergency (Left Anterolateral) Department Thoracotomy}

For unstable patient, proceed immediately to an emergency room thoracotomy. Frequently, when opening the chest to have rapid decompression of pericardial tamponade or control of the haemorrhage from the heart you could be "splashed" with blood, so is necessary. protective equipment for you and the all your team for blood infection.

Make an incision on the 5th intercostal space. For a female patient, you should ask to your colleague to mobilize cranial the breast and you make the incision in a sub mammary position. Your assistant should raise the arm to 90 degrees - this enables a lateral extension of the incision towards the axillary line. Insert a rib retractor with its joining limb on external position of the incision and in this way it does not influence your capability to increase your incision by section of the sternum and even opening the thoracic cavity on the other side, if you consider necessary. The rapid opening of the rib retractor is constantly causes rib fractures. Protect the edges of the thoracotomy with large gauzes and tell your assistant of the possibility of injuring himself from rib spikes. In situations, where it is hard to assess the right aspect of the heart and this cut the sternum transversely or even think to a full clamshell thoracotomy. There are some recommendations of dividing the sternum with a Gigli saw or a bone cutter, but in our opinion is not practical. With both you lost a lot of time and it easy to divide it it with the a pneumatic saw or if you don't have, a Liebscher knife and hammer. Pay attention to the lesion of the heart as the normal pericardium keeps the contents near to the posterior face of the sternum. To escape that, apply ascending traction of the the Liebscher knife or pneumatic saw. Opening the pericardium before splitting the sternum will make it safer as the heart will drop inside the chest and this takes place with a better visualisation on the posterior face of the sternum. The mammary arteries that will always be divided with this manoeuvre must be ligated at an early or later stage immediately after the repair of the cardiac wound.

\section{Median Sternotomy}

If you are lucky and your patient is relatively stable, it is preferable to transfer him from the emergency department to operating theatre. 
Before to start place a sandbag posteriorly, between the scapulae and a median sternotomy is every time helpful. This incision is ideal, not only for getting access to the heart, it is also convenient also for the ascending aorta but this is a rare cause of the cardiac tamponade. It is also convenient for the cross of the aorta and its branches. A common difficulty is to lose the midline of the sternum during the sternotomy. Position yourself on the left of the patient. Start with the skin incision using the cautery and continue to extend it to the anterior face of the sternum from cranial to the xiphoid. Divide the intra-clavicular ligament, usually with a diathermy, and insert the tip of a right angled clamp Lahey posteriorly to the cranial part of the sternum and push its tip at the retro manubrial space, thus creating a space for the start the section of the sternum with the pneumatic saw or Liebscher knife. This manoeuvre can lead to bleed and for the inexperienced surgeon could be alarming because you have a difficult access and is not easy to control. Stay calm! The only big arteries or veins in this zone is the innominate vein which is too deep to be damaged in this way. You'll control this bleeding after opening of the sternum with a diathermy or temporary packing with swabs. Start a median sternotomy from the sternal notch, religiously following the diathermy line. Remember that the manubrium is much harder than the body of the sternum. Therefore, special attention must be paid as the pneumatic saw or Liebscher knife may go with excess force from the manubrium to the softer proximal body of the sternum and cause an overshoot, miss the midline and result in division of the rib cartilages. The sternal retractor should be placed into the incision with its active parts including the distal portion of the manubrium. In this way we minimise the possibility of fracturing the body of the sternum on the quickly opening sternotomy incision.

\section{The Repair of the Heart}

On opening the chest with a diagnosis of the heart injury, confirm tamponade at the examen of the pericardium, unless you misdiagnosed it as cardiac injury and there is an evident active bleeding associated with other lesion. If this is the situation you should solve the bleeding temporary by compression or definitively by suture. Hemopericardium that is not related with obvious active bleeding through the injured pericardial sac, could be recognised by the distension of the pericardium or occasionally by the white blueish colour of the clot. A common mistake is not to open the pericardium because it's look normal outside. It is surprising how frequently the pericardial sac containing an important quantity of blood from which is not observable by transparency of the normal pericardium. Make a small incision with the scissors in the pericardium to check if there is a clot or use two fine clamps to lift it and make an incision in between with a blade if you don't notice any blood from outside by transparency. Make a vertical incision on the pericardium escaping injury of the phrenic nerve. The phrenic nerve passes more or less parallel to your incision. If you need an additional access to the heart, then is mandatory to add another pericardial incision on transversal direction at the caudal end of your vertical part (an inverted T). Inspect the heart and repair the defect using a 2.0 silk or a similar sized PDS. You do that by holding a needle holder in both hands - first one introducing the needle into the heart and the second for recovering it. While your assistant stops the bleeding by obstructing the heart defect with the swab, you prepare your needle at the needle holder on the end of the posterior part of your needle. Your objective is to insert as much size of needle as possible inside the cardiac cavity in your initially through and through bite to the heart so that you can take the tip through the hole as easily as possible with the needle holder of the other hand. Catch the needle with your needle holder while your colleague covers the defect controlling the bleeding and now you can insert the needle on the contralateral side of the injury from inside outwards. After the first stiches pass everything become easier and the job is almost done. If you're right handed hold with your left hand on both ends of the stitch and 
elevate them. You will see now, that the limits of the injury are appropriated in this way and you have a important reduction in the quantity of bleeding. By keeping the stitch threads up, you prepare another stitch and you complete another figure of eight fashion. Continue with more figure of eight suturing to the end.

If you need time to prepare yourself to repair the cardiac defect or if you do not feel confident to do it immediately yourself, the introduction of a Foley catheter and inflation of its balloon, will control the haemorrhage. Lock the urine port of the Foley catheter, take its tip with a clamp and introduce it into the cardiac camber through the cardiac wound. Then inflate the balloon with fluid and apply slight traction in order to obstruct the cardiac hole, but be careful that you don't exceed it with the tension otherwise you can create the cardiac defect bigger especially if the injury affect the laxer right ventricle. Apply a mosquito clamp on the catheter at the point where it comes out of the defect so that the tension of the balloon on the defect is maintained and the bleeding controlled. is You can then transfer the patient to theatre to repair the defect by yourself or by somebody else who has more experience and arrives at your help. Relatively frequently, once you introduce the needle, at the first pass, you will hear a cracking sound and the balloon will destroy. Now you will be yourself again in the condition of having a lot of blood coming out through the defect. Continue the sutures as it was described anterior.

If you have a lesion around the coronary arteries, it is mandatory to repair the defect by inserting horizontal sutures. The stich should pass under the coronaries and around the injury. It is important to control the haemorrhage but not occluding the artery. It is suitable but not mandatory to use a stich with with two needle. Stop the bleeding and suture the lesion with a continuous 5.0 prolene. If it is required, you can reinforce the sutures.

When you have a penetrating injury on the anterior part of the heart is mandatory to inspect the posterior for a concomitant through and through injury. This can be accomplished by lifting the heart outside of the pericardum, and for this manoeuvre the anaesthetist must be informed. Introduce your hand posteriorly to the heart with the tips of your finger reaching proximally to the aorta and the proximal part of the heart. With a rotation pivoting the axis of its base the heart is elevated outside of the pericardial sac. You can escape kinking of the superior vena cava and the cardiac cavities in this way, since the heart is lifted unblock. The response of the heart isn't pleasant with this manoeuvre, so suture as fast as possible the posterior lesions of the heart because it is possible rapidly progresses to bradycardia and even to asystole. As soon bradycardia appears, put rapidly the heart back to the pericardial sac. It doesn't mater if you haven't yet finished to suture the posterior injury. Even though you replace it onto its place, the heart is very sensitive and may progress to a non-responsive bradycardia. In this situation, it is suitable to put in warm saline around $400 \mathrm{C}$ on the heart which causes it to have normal activity again, even occasionally developing tachycardia. Sometimes as soon as the heart is elevated, it responds quickly with an arrhythmia that it makes difficult to evaluate its posterior aspect. By inserting one or two folded abdominal swabs between heart and the pericardium, you can obtain partial elevation. In this way you offer time to adapt at the lift position. Try to elevate again the heart to progress with the evaluation and suture when you have a good condition and the rhythm I relatevely normal. Permanently check if other intrapericardial organs like inferior vena cava are not injury. Suture the pericardium with a continuous absorbable suture and with a $2 \mathrm{~cm}$ gap at the distal part of your closure where you insert an underwater drain with its tip in front of the gap. The suture o the proximal part of the pericardium require attention because small holes left behind the stitches in large steps can progress to herniation of the auricles.

\section{The Closure the Sternum}

Getting the needle and the wire through the sternum is time consuming if you are not skilled with the closing of the sternotomy The 
needle can be aided to pass through the sternum by applying the needle holder much easier at the junction of the proximal and middle third and then advancing the needle in a vertical direction. As the forced is applied with the needle on the sternum, sometimes the sternum give way unexpectedly and the needle pass quickly, risking damaging underlying structures. You escape this by using a lame or other device with a concavity facing upward, applied under the sternum at the expected point of penetration.

Control the bleeding from the limits of the sternum by using electrocautery or bone wax. You should apply not too much wax because the excess application is associated to increased risk of infection of the sternum. The same is true if the limits of the divided sternum are not well estimated.

\section{Recommended Reading}

1. Degiannis E, Bowley MD, Westaby S. Penetrating cardiac injury. Ann R Coll Surg Engl. 2005 Jan;87(1):61-3.
2. Degiannis E, Loogna P, Doll D, Bonanno F, Bowley DM, Smith MD. Penetrating cardiac injuries: recent experience in South Africa. World J Surg. 2006;30(7):1258-64.

3. Degiannis E, Smith MD. Pot pouri of heuristics in penetrating in penetrating trauma to the chest. ANZ J Surg. 2008;78(12):1103-5. doi: 10.1111/j.1445-2197.2008.04759.x.

4. Degiannis E, Zinn RJ. Pitfalls in penetrating thoracic trauma (lessons we learned the hard way...). Ulus Travma Acil Cerrahi Derg. 2008;14(4):261-7.

5. Navsaria PH, Nicol AJ. Haemopericardium in stable patients after penetrating injury: is subxiphoid pericardial window and drainage enough? A prospective study. Injury. 2005;36(6):745-50. Epub 2005 Mar 28.

6. Saadia R, Levy RD, Degiannis E, Velmahos GC. Penetrating cardiac injuries: clinical classification and management strategy. Br J Surg. 1994;81(11):1572-5.

7. Vassiliu P, Yilmaz T, Degiannis E. On the ideal emergency thoracotomy incision. World J Surg. 2014 Apr;38(4):1001-2. doi: 10.1007/s00268-013-2253-9.

8. Velmahos GC, Degiannis E, Souter I, Allwood AC, Saadia R. Outcome of strict policy on emergency department thoracotomies. Arch Surg. 1995;130(7):774-7.

9. Velmahos GC, Degiannis E, Souter I, Saadia R. Penetrating trauma to the heart: relatively innocent injury. Surgery. 1994; 115(6):694-7.

10. Asensio JA, Petrone P, Snachez JA, Degiannis E Cardiac Injuries. In: Therapy of trauma and surgical critical care (2nd ed). Editors: Asensio JA, Trunkey DD. Elsevier. 2016.

11. Degiannis E, Mogabe DP, Doll D. Penetrating cardiac trauma. In: Penetrating Trauma: A practical guide on operative technique and peri-operative management (2nd ed). Editors: Velmahos GC, Degiannis E, Doll D. Springer. 2017. 